\title{
The Universal Periodic ReView: A DeVICE FOR BUILding UP COOPERATION WITH HUMAN RIGHTS MECHANISMS IN BRAZIL AND MIGRATION Protection
}

\author{
Fernanda Duarte ${ }^{1}$ \\ Rafael Mario Iorio Filho ${ }^{2}$
}

\section{Introduction}

This presentation is part of a research project developed within the scope of the international academic cooperation program between Estácio de Sá University, the Fluminense Federal University and Birmingham City University, under the Erasmus + program, electing as its motive theme the Universal Periodical Review- UPR, adopted by the Human Rights Council of the United Nations. One of the objectives of this UPR mechanism is to assure that human rights obligations and commitments are fulfilled by the States in order to promote the universality and indivisibility of civil, political, economic, social, and cultural rights as well as the right to development. In this sense, one of the axes of relevance for improvement of the human rights situation in every country with significant consequences for people all around the globe focuses on building up a legal framework (with international legal sources or roots) that could be articulated locally as a shield for those who (legally bound to the State) find themselves in situations of human rights violations. This shield makes the State internationally accountable for violating its duty to comply with international norms. Even though this spectrum of legal normativity is not enough to assure human rights full effectiveness in all the levels and complexities of human life and existence, it brings the symbolic weight of the idea of the rule of law. In this opportunity, we intend to present the legal framework for the promotion and protection of human rights in Brazil, taking into account Brazil's constitutional order and its relation with international legal instruments. Then considering Brazil's performance within the UPR 3rd Cycle, 2017, 27th Session, we will discuss Brazil's compliance with this international environment of instruments for protecting human rights taking the International Convention on the Protection of the Rights of All Migrant Workers and Members of Their Families recommendation as an example to be studied.

\section{Human rights and international law}

The theme of Human Rights (HR) is open to a series of different perspectives that pass through different areas of human knowledge, both because it is said that human rights are crosscutting, and because it is a theme that runs perpendicularly through society. This transversality would reinforce the aspects of the universality, indivisibility and interdependence of Human Rights.

Thus, the studies regarding HR can deal with many different themes and approaches, such as reports of violations, strategies in education for HR, social and political actions to be taken in favor of HR, costs and funding mechanisms for the promotion and protection of $\mathrm{HR}$,

\footnotetext{
${ }^{1}$ Professor of Law. Federal Judge. PhD - PPGD/UNESA, PPGJA e INCT-InEAC/UFF. E-mail: fduarte1969@ yahoo.com.br

2 Professor of Law. PhD - PPGD/UNESA, PPGJA e INCT-InEAC/UFF. E-mail: rafa.ioriofilho@gmail.com
} 
initiatives to empower vulnerable groups, the consolidation of democracy as a prerequisite for $\mathrm{HR}$, tensions between majorities and minorities, the relationship between culture and HR, conflicts between freedom and equality and so forth.

A more formal study can also be carried out, focusing on the regulatory framework that will enable the adoption of actions to promote and protect HR. This can be considered the legal environment which is linked to a prescriptive approach and would help the States to build up strong institutions committed to the theme.

This is exactly the main interest of our investigation now, since compliance to international human right law is one of the aspects to be reviewed by the UPR mechanism and it has been part of the recommendations made to the Brazil in its last cycle, in 2017.

As we are dealing with international law, first we will see how international law gets into effect in Brazil, then we will discuss the some special features of HR law in Brazil in relation to the Brazilian Constitution and finally we will exam Brazil's performance in the last UPR Cycle regarding HR international law, considering the case of the International Convention on the Protection of the Rights of All Migrant Workers and Members of Their Families.

\section{The system of integration of international treaties in Brazil}

As it is well known, the term treaty is used generically to describe a variety of international legal instruments, including conventions, agreements, arrangements, protocols, charters etc. But, in a stricto sensu meaning, treaties are binding instruments (based on the principle of pacta sunt servanda which determines that agreements must be $\mathrm{kept}^{3}$ ). In this sense, a treaty is a binding formal written document that establishes obligations between two or more subjects of international law, either being States (nations) and/or international organizations. In this sense treaties are known as hard law. However, if this binding feature is not present, they are known as soft law; in other words, they are based on and binding for moral reasons only and are not subject to judicial adjudication.

Even though a treaty might be signed between the parties, it is necessary to understand which other measures should be taken within a State's internal system so that the treaty can be considered in force or if the signature is enough to give effectiveness to the treaty. And this relationship between the international legal order and the domestic legal order engages the debate on monism and dualism. ${ }^{4}$

Throughout Brazilian legal history, the country has been acknowledged as a dualist system. However, considering the particularities of the Brazilian system now, this distinction

\footnotetext{
${ }^{3}$ This binding effect is expressed in article 26 of VCLT (the Vienna Convention of the Law of Treaties, from 1969).

${ }^{4}$ In general, scholars point out that there two different legal traditions when considering the integration of international treaties into the national order: the monism and the dualism. The monist system understands that international law does not need to be integrated into domestic law. The act of ratifying an international treaty is enough to the incorporation of that international law into national law. On the other hand, for the dualist system international law is not directly applicable within the internal legal order. So in order to be applied locally by the national courts, first it must be translated or integrated into domestic legislation and there is a variety of ways in which domestic systems incorporate international law. A critical view of this classification is offered by Charlesworth, Hilary, Madelaine Chiam, Devika Hovell, and George Williams, eds. The Fluid State: International Law and National Legal Systems. Sydney, Australia: Federation Press, 2005.
} 
has little applicability, since we can be considered moderate monists and/or dualists as we will discuss latter.

Based on the current Constitution, the process of internalizing international law has the following steps:

I. the President of the Republic, in the exercise of his powers foreseen in art. 84, VIII, of the Federal Constitution, celebrates the international treaty;

II. then, as provided for in art. 49, I, of the Federal Constitution, the National Congress is responsible for endorsing the international treaties signed by the President of the Republic, which is done by means of a Legislative Decree;

III. when the referred Legislative Decree is published, the treaty is ratified, by the President upon deposit of the respective instrument, confirming the Brazilian desire to be bound by the terms of that document;

IV. finally, the treaty is promulgated by a presidential decree and becomes effective after its publication in a daily official report called Diário Oficial which is broadly similar to the U.S. Federal Register, but not confined to federal government communications, once Federal legislative acts, as well as judicial decisions (including federal courts of all tiers), are communicated to the public through these reports.

This means that as long as the President does not promulgate the treaty by decree, the instrument is not capable of producing any effects at the domestic level, even if duly ratified at the international level, since it is still devoid of validity and enforceability at the level of positive Brazilian domestic law.

Therefore, if the treaty has not been yet admitted as part of the domestic law:

- there is no direct effect which means that the ability of the international standard to have an immediate impact on the rights and obligations of individuals in the legal sphere is still lacking,

- there is no immediate applicability meaning that Brazil does not accept the automatic validity of the international standard in the domestic legal system.

By the way, this is the exact position taken by the Brazilian Supreme Court on the matter, as shown in Carta Rogatória (Rogatory Letter) No. 8279, for instance.

This legislative procedure described before has prevailed as the rule for international law integration for treaties on general topics and for human rights treaties, within Brazilian law until 2004, when the current Constitution was amended and a third paragraph ${ }^{5}$ was added to article 5 (which is the normative paramount clause of Brazilian legislation regarding HR since the 1988 Constitution promulgation).

This change deals exactly with the efficacy of HR treaties in Brazilian law and their normative status regarding the statutory legislation. It has given a prestigious framework for treaties of human rights and reinforces the constituent position that the procedure for treaties integration in Brazil remains dualistic. Now, depending on the quorum of approval, the HR convention becomes part of the Brazilian law having status of constitutional amendments, if

\footnotetext{
${ }^{5}$ See Constitutional Amendment No. 45.
} 
approved in each House in two rounds of voting, by three fifths of the votes of its member (either being congressmen and senators ), as provided for in paragraph 3, art 5 of the 1988 Constitution ${ }^{6}$.

But even though the HR treaties stand at the top of the hierarchy of Brazilian norms, whether from the legal perspective or from the political perspective, the formal requirement for their approval makes the situation of HR treaties more laborious which may pose an extra burden to the integration process.

Brazil's performance within the UPR 3rd Cycle, 27th Session, 2017 to the theme "Acceptance of international norms" and the case of the International Convention on the Protection of the Rights of All Migrant Workers and Members of Their Families.

Regarding Brazil's performance within the UPR, $3^{\text {rd }}$ Cycle, twenty recommendations were made considering the HR international law framework.

Basically, the recommendations deal with either signing or ratifying a specific treaty or its protocols or amendments. Almost 30 countries have made recommendations, as we can see in the following chart:

\begin{tabular}{|c|c|c|c|}
\hline International HR treaty in focus & $\begin{array}{l}\text { Frequency of } \\
\text { recommendation }\end{array}$ & Origin of recommendation & What is expected from Brazil \\
\hline $\begin{array}{l}\text { the Convention on the Non- } \\
\text { Applicability of Statutory Limitations } \\
\text { to War Crimes and Crimes against } \\
\text { Humanity }\end{array}$ & $1 \mathrm{x}$ & (Armenia) & Ratify the treaty \\
\hline $\begin{array}{l}\text { the Optional Protocol to the } \\
\text { Convention against Torture and } \\
\text { Other Cruel, Inhuman or Degrading } \\
\text { Treatment or Punishment \& the UN } \\
\text { Nelson Mandela Rules }\end{array}$ & $1 \mathrm{x}$ & (Czechia) & $\begin{array}{l}\text { Proceed with the enactment of } \\
\text { legislation effectively } \\
\text { implementing the treaty, at both } \\
\text { state and federal level } \\
\text { Adopt measures to adhere to the } \\
\text { rules }\end{array}$ \\
\hline $\begin{array}{l}\text { the Arms Trade Treaty and adapt its } \\
\text { national legislation to the Treaty }\end{array}$ & $1 \mathrm{x}$ & (Guatemala) & Ratify the treaty \\
\hline $\begin{array}{l}\text { the Kampala amendments to the } \\
\text { Rome Statute }\end{array}$ & $1 \mathrm{x}$ & (Liechtenstein) & $\begin{array}{l}\text { Ratify the amendments with a } \\
\text { view to contributing to the } \\
\text { activation of the jurisdiction of } \\
\text { the International Criminal Court } \\
\text { over the crime of aggression in } \\
2017\end{array}$ \\
\hline \multirow[t]{2}{*}{$\begin{array}{l}\text { the International Labour } \\
\text { Organization (ILO) Freedom of } \\
\text { Association and Protection of the } \\
\text { Right to Organise Convention, } 1948 \\
\text { (No. 87) }\end{array}$} & $1 \mathrm{x}$ & (Ecuador) & Ratify the treaty \\
\hline & & $\begin{array}{l}\text { (Albania; Angola; } \\
\text { Argentina; Montenegro and } \\
\text { Portugal) }\end{array}$ & Ratify the treaty \\
\hline
\end{tabular}

\footnotetext{
${ }^{6}$ This is the mentioned text of paragraph 3: "International human rights treaties and conventions which are approved in each House of the National Congress, in two rounds of voting, by three fifths of the votes of the respective members shall be equivalent to constitutional amendments."
} 


\begin{tabular}{|c|c|c|c|}
\hline $\begin{array}{l}\text { the Optional Protocol to the } \\
\text { International Covenant on Economic, } \\
\text { Social and Cultural Rights }\end{array}$ & $4 x$ & $\begin{array}{l}\text { (El Salvador and Ukraine) } \\
\text { (Gabon) } \\
\text { (Finland) }\end{array}$ & $\begin{array}{l}\text { (and accept the competence of } \\
\text { the Committee as regards the } \\
\text { inquiry procedure and inter- } \\
\text { State communications) }\end{array}$ \\
\hline $\begin{array}{l}\text { the Domestic Workers Convention, } \\
2011\end{array}$ & $2 x$ & $\begin{array}{l}\text { (Nicaragua) } \\
\text { (Philippines) }\end{array}$ & Ratify the treaty \\
\hline $\begin{array}{l}\text { the Optional Protocol to the } \\
\text { Convention on the Rights of the Child } \\
\text { on a communications procedure }\end{array}$ & $4 x$ & $\begin{array}{l}\text { (Albania; El Salvador; } \\
\text { Georgia; Montenegro and } \\
\text { Liechtenstein) } \\
\text { (Ukraine) } \\
\text { (Croatia and Mongolia) } \\
\text { (Czechia) }\end{array}$ & $\begin{array}{l}\text { Ratify the treaty } \\
\text { (before the next universal } \\
\text { periodic review cycle) }\end{array}$ \\
\hline $\begin{array}{l}\text { the International Convention on the } \\
\text { Protection of the Rights of All } \\
\text { Migrant Workers and Members of } \\
\text { Their Families }\end{array}$ & $7 x$ & $\begin{array}{l}\text { (Sierra Leone) } \\
\text { (Chile; Indonesia and Sri } \\
\text { Lanka) } \\
\text { (Togo) } \\
\text { (Guatemala) } \\
\text { (El Salvador) } \\
\text { (Philippines) } \\
\text { (Ecuador) }\end{array}$ & $\begin{array}{l}\text { Sign the treaty } \\
\text { Finalize the domestic } \\
\text { procedures to accede to the } \\
\text { treaty }\end{array}$ \\
\hline
\end{tabular}

Brazil's response: the level of implementation and the case of the International Convention on the Protection of the Rights of All Migrant Workers and Members of Their Families (ICRMW)

Brazil has supported all the recommendations with no exceptions, but it is necessary to follow the measures that have been taken by the country in order to verify the level of implementation, considering all the due procedures that should be taken domestically in order to internalize an international treaty.

For the purpose of this presentation, we will deal with one specific case: the International Convention on the Protection of the Rights of All Migrant Workers and Members of Their Families ${ }^{7}$ which was chosen because of its the numbers of recommendations (seven), being the most recurrent topic within the theme "Acceptance of international norms".

Nowadays migration issues are seen as a humanitarian crisis and there are many recent episodes in the world's history that support this view ${ }^{8}$. But it can be portrayed with different

\footnotetext{
${ }^{7}$ The full text of the treaty can be found here: https://www.ohchr.org/EN/ProfessionalInterest/Pages/CMW.aspx

${ }^{8}$ The seriousness of the migration phenomenon and its grave consequences specially to women and children migrants is expressed by Ms. Kate Gilmore, Deputy High Commissioner for Human Rights in her Statement in 31st Session of the Committee on the Protection of the Rights of All Migrant Workers and Members of Their Families that took place on 2 September 2019, Geneva. "the significance of today's migration for the future of justice, sustainability, peace and prosperity in our world. As old as human history, nonetheless, it is our era that is distinguished by unprecedented movement within and across borders. That same migration is a phenomenon from which so many of us here have benefited directly. Yet, for the vast majority of those who never will enjoy the privilege of sitting in such rooms, migration involves a flight from fear; not a choice to explore new frontiers nor an achievement to celebrate. Precarious migration within and across borders, is invariably more than a humanitarian concern alone; the many indignities of flight, reception and destination without choice combine to
} 
shades as well, as the Chair of the UN Committee on the Protection of the Rights of All Migrant Workers and Members of Their Families calls attention to:

Migration, which is a continuous cycle of human progression, is often portrayed as a crisis. It need not always be seen as such and is and will not go away. Treating it as a problem instead of a natural process is not a solution according to José Brillantes, Chair of the Committee on the Protection of the Rights of All Migrant Workers and Members of Their Families (CMW). Population growth, climate change, desertification, war and famine will continue to force people to migrate and migrants will also choose voluntarily under some circumstances to move in search of better employment opportunities, for example. Nevertheless, while root causes persist, migrants will continue to take various measures including risks as long as there is a cross-border supply and demand for work and inadequate legal migration frameworks ${ }^{9}$.

It is one of the most important topics of contemporary times which has attracted attention not only in the academic world, but as well in the international arena as part of the UN political, legal and social agenda, demanding policies and legal commitment. As a result of this necessity international pacts are made, such as the ICRMW.

The ICRMW is a comprehensive document which establishes basic standards for the laws and the judicial and administrative procedures to be followed by individual States in order to protect migrant workers and members of their families from exploitation and human rights violations regardless of their migration status. It can be considered as a minimum moral standard to guide the protection and promotion of migrants HR, reaffirming the fundamental rights that are cherished in the Universal Declaration of Human Rights and in the other international human rights documents. Equality of treatment and dignity can be considered as the core values of the treaty which emphasizes that migrants are human beings and because of this inherent condition are entitled to have access to a minimum degree of protection.

The Convention endorses that all migrant workers and members of their families without distinction of any kind such as sex, race, colour, language, religion or conviction, political or other opinion, national, ethnic or social origin, nationality, age, economic position, property, marital status, birth or other status are entitled to due respect and protection. It also acknowledges civil and political rights with a view to the particular situation of migrant workers ${ }^{10}$. The instrument bans collective expulsion stating that each case of expulsion shall be examined and decided individually. Economic, social and cultural rights of migrant workers in view of their particular situation are set out as well, for example, the right to urgently required medical treatment or the right of access to education for children of migrant workers.

place irregular migrants - as individuals and as families - in comprehensive human rights crises. Refugees fleeing conflict, persecution. People compelled to flee extreme poverty, environmental degradation, the impacts of climate change; the absolute absence of decent work. Families responding to gang violence, to lack of education and healthcare for their children, to the consequences of long-term separation from family members." Her full statement is found here: (https://www.ohchr.org/en/NewsEvents/Pages/DisplayNews.aspx?NewsID=24947\&LangID=E)

${ }^{9}$ Statement by the Chair of the Committee on the Protection of the Rights of All Migrant Workers and Members of Their Families, Mr. José Brillantes, on the need for ensuring a human rights based approach to the Global Compact on Migration. 20 October 2017. https://tbinternet.ohchr.org/Treaties/CMW/Shared\%20Documents/1_Global/INT_CMW_STA_8317_E.pdf ${ }^{10}$ Amongst the rights granted in the Convention, the migrant workers and members of their families have the right to have consular or diplomatic authorities informed in the event of detention. They may be expelled from the territory of a State Party only in pursuance of a decision taken by the competent authority in accordance with law.), and contains provisions on violations of migration law and respective prohibitions (such as the prohibition of collective expulsions) 
The ICRMW also extends its protection to the entire migration process of migrant workers and members of their families, including preparation for migration, departure, transit and the entire period of stay and remunerated activity in the State of employment as well as return to the State of origin or the State of habitual residence.

Regarding its review mechanisms ${ }^{11}$, the Convention establishes a Committee on the Protection of the Rights of All Migrant Workers and Members of Their Families $(C M W)^{12}$. The Committee sits in Geneva and, as usual, is a body of independent experts in charge of monitoring the states parties in the implementation of their obligations under the Convention. The states parties must report regularly on the measures taken to implement the provisions of the Convention and document both progress and difficulties ${ }^{13}$. Its first held session was held in March 2004.

Although the ICRMW was adopted by the UN (Resolution $45 / 158$ by the General Assembly) on 18 December 1990, it entered into force 13 years later, on 1 July 2003, when the requirement of having 20 signatures was achieved. Even though it is considered one of the most important conventions regarding HR international framework, it has been facing a lot of difficulties to be ratified or acceded ${ }^{14}$ by the countries. By 1 October 2005, 33 States had ratified it or acceded to it. And in 2019, the number of countries that have ratified it sums up 55 countries ${ }^{15}$, as shown by the chart provided by the UN Human Rights Office of the High Commissioner that follows ${ }^{16}$. The HR Office registers that up to last August 130 countries have taken no action towards the accession of the treaty- which is the Brazilian case.

\footnotetext{
${ }^{11}$ Other review mechanisms are also designed. In addition to the state reporting procedure, states parties may recognize the competence of the Committee to consider interstate and individual complaints. This mechanism has not yet come into effect, however, as less than 10 states have recognized the Committee's competence in this matter.

${ }^{12}$ More information about the CMW is available here: https://www.ohchr.org/EN/HRBodies/CMW/Pages/CMWIntro.aspx

${ }^{13}$ These reports are to be periodical, in this fashion: each state party is to submit a first report to the Committee within the first year following ratification and further reports are due on a five-yearly basis.

${ }^{14}$ According to the basic categories of international law: "Ratification defines the international act whereby a state indicates its consent to be bound to a treaty if the parties intended to show their consent by such an act. In the case of bilateral treaties, ratification is usually accomplished by exchanging the requisite instruments, while in the case of multilateral treaties the usual procedure is for the depositary to collect the ratifications of all states, keeping all parties informed of the situation. The institution of ratification grants states the necessary time-frame to seek the required approval for the treaty on the domestic level and to enact the necessary legislation to give domestic effect to that treaty. [Arts.2 (1) (b), 14 (1) and 16, Vienna Convention on the Law of Treaties 1969]" whereas "Accession is the act whereby a state accepts the offer or the opportunity to become a party to a treaty already negotiated and signed by other states. It has the same legal effect as ratification. Accession usually occurs after the treaty has entered into force. The Secretary-General of the United Nations, in his function as depositary, has also accepted accessions to some conventions before their entry into force. The conditions under which accession may occur and the procedure involved depend on the provisions of the treaty. A treaty might provide for the accession of all other states or for a limited and defined number of states. In the absence of such a provision, accession can only occur where the negotiating states were agreed or subsequently agree on it in the case of the state in question. [Arts.2 (1) (b) and 15, Vienna Convention on the Law of Treaties 1969]" (UN Glossary of terms relating to Treaty actions. https://treaties.un.org/pages/Overview.aspx?path=overview/glossary/page1_en.xml)

15 As of December 2019, the following 55 states have ratified the Convention: Albania, Argentina, Algeria, Azerbaijan, Bangladesh, Belize, Bolivia, Benin, Bosnia and Herzegovina, Burkina Faso, Cape Verde, Chile, Colombia, Congo-Brazzaville, East Timor, Ecuador, Egypt, El Salvador, Fiji, Gambia, Ghana, Guatemala, Guyana, Guinea, Guinea-Bissau, Honduras, Indonesia, Jamaica, Kyrgyzstan, Lesotho, Libya, Madagascar, Mali, Mauritania, Mexico, Morocco, Mozambique, Nicaragua, Niger, Nigeria, Paraguay, Peru, Philippines, Rwanda, Sao Tome and Principe, Senegal, Seychelles, Sri Lanka, Saint Vincent and the Grenadines, Syria, Tajikistan, Turkey, Uganda, Uruguay, and Venezuela. On the other hand, Armenia, Benin, Cambodia, Cameroon, Chad, Comoros, Gabon, Haiti, Liberia, Palau, Serbia and Montenegro, Sierra Leone, and Togo have signed the Convention but not yet ratified it.

${ }^{16}$ The chart is available here: https://www.ohchr.org/EN/HRBodies/CMW/Pages/CMWIndex.aspx
} 


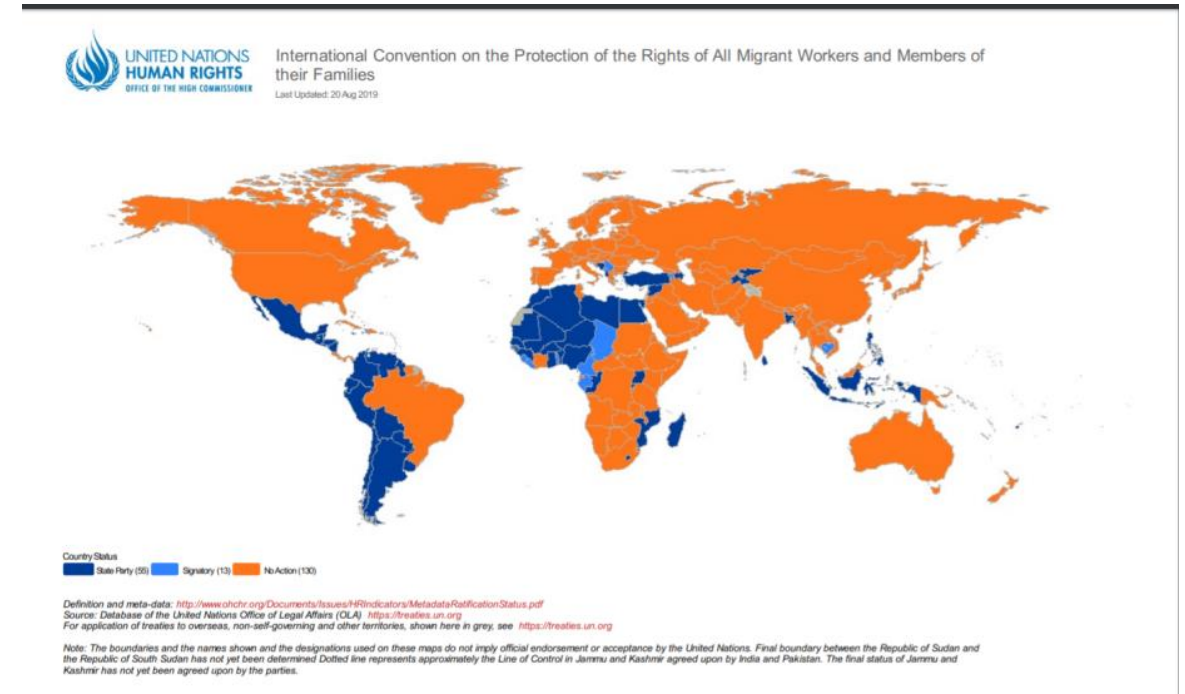

It is interesting to notice that the countries that have adopted the Convention are primarily countries of origin of migrants (such as Mexico, Morocco, and the Philippines) and for them the treaty can be considered as an important shield to protect their citizens living abroad. But no migrant-receiving state either in Western Europe or in North America has ratified the Convention. Neither have other relevant receiving countries, such as Australia, Arab states of the Persian Gulf, India and South Africa ratified the Convention. As for the Mercosul countries, all the states within the agreement have adhered to the document, except for Brazil. It is also interesting to see that countries that have a reputation of championing the HR protection have kept quiet and the ICRWM is not domestically binding for them which points to the need for more studies about this reticent attitude.

Regarding Brazil's position towards the ICRMW, despite the seven recommendations that were made in the last UPR cycle, the country has not yet promoted any effective measures towards the treaty accession.

As it is part of the Brazilian legislative rite there are two possibilities of starting the process of internalizing a treaty. The President can sign the treaty ad referendum of the National Congress (according to art.84, VIII of the 1988 Constitution) or he can defer directly to the Congress which has the competence to decide conclusively on international treaties (as provided for in art. 49, I of the 1988 Constitution). Only in this case after the approval by the Congress, the President will have the capacity to accede to the Convention. And, as we have previously discussed, the instrument itself to become effective within Brazilian law needs to be promulgate by a presidential decree.

So, choosing the second option, in December 2010, the Brazilian President sent a message to the National Congress (Mensagem $n^{\circ}$ 696, de 2010) urging the Legislature to consider the Convention and the possibility of accession. The Brazilian Congress in its turn has been quite dormant. The Congress waited until 2015 to create a special commission responsible to evaluate the presidential message. Since then, nothing else has happened ${ }^{17}$. 17 The legislative processing regarding the approval of the ICRMW (Message 696/2010) can be followed here:
https://www.camara.leg.br/proposicoesWeb/fichadetramitacao?idProposicao=489652 
Even though Brazil's position follows the majority of countries regarding the instrument, which could suggest a low level of implementation, from a normative perspective, it cannot be considered as worthless in term of legal protection.

In the same year of the UPR, $3^{\text {rd }}$ cycle, Brazil passed a new law regarding migrants: Law 13.445 which is known as the New Migration Law ${ }^{18}$. This statute is acknowledged as a change of paradigm within Brazilian law regarding migration and towards human rights protection ${ }^{19}$. This law in general terms mirrors the protection enshrined in the ICRMW, affirming the same goals (equal treatment and dignity) as well as a catalogue of fundamental rights, even to undocumented migrants. However, the law makes no direct mention of migrants' family members.

\section{Our final comments}

From what we have studied so far, under a strict legal normative evaluation, we can say in general that the Brazilian normative system has adopted a position of fair appreciation of HR law, both internationally and internally, in an effort to follow those western countries with strong legal traditions, in order to recognize human dignity as the core and foundation of the democratic rule of law, even though some treaties are still in need be internalized.

On one hand, the domestic procedures that are required to be followed, despite the constitutional change we have already mentioned towards HR international law, stress the role of state sovereignty; on the other these same procedures work as hindrances towards HR international law once they stand as (political, legal and cultural) domestic obstacles to be overcome.

At the same time, if we take into consideration the recommendation regarding the ICRMW, it is true that Brazil has not acted effectively in the direction of the internalization of the ICRMW, which might be understood as a low level of implementation, but on the other hand domestic legislation was passed granting migrants the same kind of protection which shows a commitment to the idea of the rule of law.

So the question that arises is: is it enough? Despite the role of the rule of law as a tool for protection and promotion of HR, in the real world, if HR are in fact to be fully realized for all Brazilians and migrants in Brazil, there is a challenge that has yet to be met.

\footnotetext{
18 An actual copy of the law published in the Diário Oficial is provided by ACNUR here: https://www.acnur.org/fileadmin/Documentos/BDL/2017/11166.pdf

19 See TRAUB, Isabella. Lei de Migração: um avanço para os direitos humanos, Novo Jurista. março 25, 2018 : https://novojurista.com/2018/03/25/lei-de-migracao-um-avanco-para-os-direitos-humanos/
} 


\title{
The InCREMENTAL ReSTRICTION OF THE Death Penalty in MyanmaR: A STEP TOWARDS ABOLITION?
}

\author{
Jon Yorke ${ }^{1}$
}

\begin{abstract}
Myanmar's political and legal institutions are engaged in a constitutional conversation which has created an incremental approach to restricting the death penalty. This dialogue has historically focused on the internal mechanisms expressing the evolving constitutional competences of the President, the parliament (Pyidaungsu Hluttaw) the courts, and the Myanmar National Human Rights Commission (MNHRC). Since 1988 the military government has ceased imposing executions but allowed the capital judicial process to impose death sentences, and following the adoption of the Constitution in 2008, the hybrid military and civilian governance of Myanmar has continued the de fact abolitionist position with the non-imposition of executions. This internal process has revealed an incremental restriction of the punishment, which it is argued is also reflected in Myanmar's engagement with the international community on the death penalty. This is most significantly experienced in the country's shift in perspectives in the UN General Assembly's biennial vote on the Resolution on the moratorium on the use of the death penalty, and in the first two cycles of Myanmar's Universal Periodic Review.
\end{abstract}

This paper argues that there are identifiable incremental stages to Myanmar's restriction of the death penalty, which are:

(a) 1947-1988 that includes a fully functioning Burmese capital judicial system and the imposition of executions in the era of an absence of an international commitment for global abolition;

(b) 1989-2013 the maintenance of a partially functioning Myanmar capital judicial process with a rejection of the multilateral initiatives and international principles promoting global abolition; and,

(c) 2014 to 2020 the maintenance of a partially functioning Myanmar capital judicial process and an abstaining from affirming the multilateral initiatives and international principles promoting global abolition.

Whilst it is by no means a forgone conclusion that the next incremental step towards abolition will be taken - and there could be a step backwards - the passage of time will tell whether the argument will come to fruition that following the Myanmar National Human Rights Commission's Workshop on the Death Penalty in 2017, the current constitutional interaction on the death penalty can reasonably allow for the next incremental stage to be take in:

(d) the process for an official moratorium to transition this de facto abolitionist position into a de jure domestic legal abolition, and then for Myanmar to positively engage with the international efforts promoting global abolition.

\footnotetext{
${ }^{1}$ LLB (Hons); LLM; PhD; Professor of Human Rights and Director of the Centre for Human Rights, BCU School of Law email: jon.yorke@bcu.ac.uk
} 